\title{
Subsoil root activity in tree-based cropping systems
}

\author{
Johannes Lehmann* \\ College of Agriculture and Life Sciences, Department of Crop and Soil Science, 909 Bradfield Hall, Cornell \\ University, Ithaca, NY 14853, USA
}

Received 3 May 2002; accepted in revised form 11 January 2003

Key words: agroforestry, modeling, nutrient cycling, root activity, subsoil resources, tree-based cropping system

\begin{abstract}
An increasing number of studies indicate that (i) nutrient and water resources can be abundant in the subsoil and (ii) trees have deep root systems that can possibly reach these resources. It is less clear whether subsoil resources are actually improving water and nutrient status of tree-based cropping systems and whether they are significantly increasing crop production and yield. To answer such a question, the distribution of nutrient and water uptake by trees needs to be quantified. So-called 'root activity distributions' give valuable information about actual subsoil use by trees whereas studies on root length or mass distributions do not often correlate with uptake distributions. Despite the usually lower relative root activity in the subsoil compared to the topsoil per unit soil, the large volume of subsoil in comparison to mostly shallow topsoil is an important resource for crop nutrient and water uptake. The present study compares published root activity distributions using the model Activity $=A_{\max }\left(1-k^{\text {depth }}\right)$. The obtained regression constants $k$ of $0.91-0.99$ determined in this publication reflect the values computed by an earlier published survey for root biomass ranging from tundra to those of temperate forest biomes. Thus, tree crops can have shallow root activity and $75 \%$ of their total root activity in the first $0.1 \mathrm{~m}$ of soil, or very deep root activity with more than $90 \%$ below $0.1 \mathrm{~m}$. Neither environmental factors (i.e., climate and soil properties available from these publications) nor plant species explain differences of root activity distributions with depth. The deepest root activity is found for fruit trees such as citrus, guava and mango. Shaded crops such as coffee and cacao tend to have shallower root activity than fruit trees. Monocots including oil palm, coconut or banana have root activity that can be both deep and shallow. Regional and temporal variations of subsoil root activity for the same tree species are significant and generally larger than differences between species. Root activity patterns of tree crops appear to be sufficiently flexible to allow for subsoil resource use. Consequently, management such as pruning, fertilization, liming and irrigation are shown to significantly affect subsoil root activity.
\end{abstract}

\section{Introduction}

The vertical uptake distribution of water and nutrients from soil is an important study topic because soil resources are not equally distributed throughout the soil profile. Root distribution of field crops (Van Noordwijk and Brouwer, 1991) as well as other plant communities (Canadell et al., 1996) have been summarized in sufficient detail to allow for some general conclusions on subsoil resource use, but this level of information is not yet available for tree-based cropping systems. In this publication tree-based cropping

\footnotetext{
* FAX No: +001-607-255-3207. E-mail: CL273@ cornell.edu.
}

systems are defined as all land-use systems where trees play an important part in the production. These are comprised of fruit tree plantations, but also simultaneous and sequential agroforestry systems. Especially in tree-based cropping systems, subsoil resource use can be important for plant nutrition (Comerford et al., 1984) and is one of the main reasons for integrating trees into cropland (Sanchez, 1995). In mixed cropping systems with trees, the knowledge of the vertical root distribution is crucial for the optimization of resource use (Van Noordwijk et al., 1996). The ability of trees to access subsoil nutrients and water depends on several factors such as tree species, soil physical 


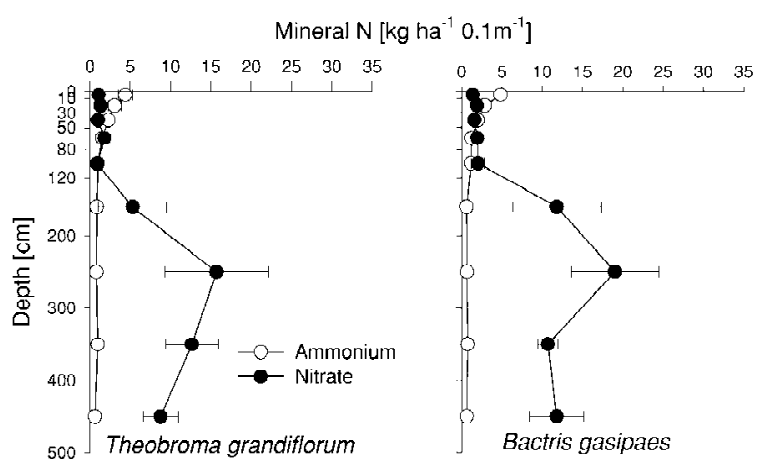

Mineral N $\left[\mathrm{kg} \mathrm{ha} \mathrm{a}^{-1} 0.1 \mathrm{~m}^{-1}\right]$

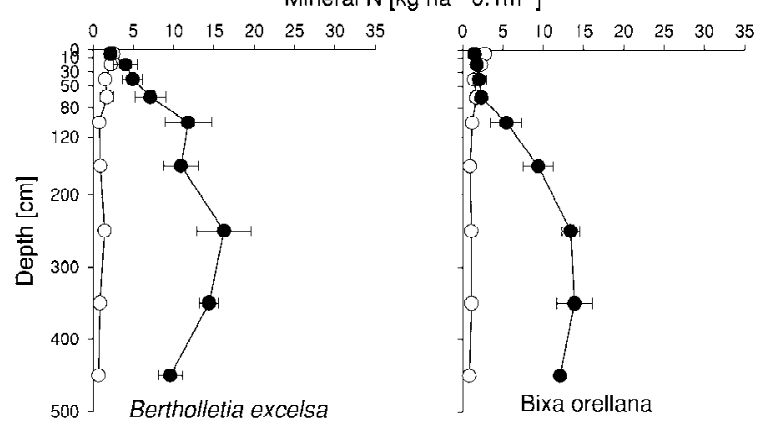

Figure 1. Nitrate and ammonium contents of a Xanthic Ferralsol in the Central Amazon under four different tree crops $(0.5 \mathrm{~m}$ distance from stem; two samples from two trees per replicate) before the rainy season; mineral $\mathrm{N}$ extracted with $1 \mathrm{~N} \mathrm{KCl}$ for $2 \mathrm{~h}$ and analyzed with a segmented flow analyzer (Scan Plus Analyzer, Skalar Analytical B.V., Breda, The Netherlands); means and standard errors $(N=3$; randomized complete block design).

and chemical properties, tree management and the cropping system. In the following, I discuss the importance of subsoil resources, the ability of tree crops to use them, the factors influencing this ability, and management effects on subsoil root activity.

\section{Subsoil resources}

The quantification of subsoil root activity is obsolete if no resources are present in the subsoil. Recent research shows that considerable amounts of plantavailable nutrients and water can be present below the topsoil (more than 10-30 cm deep) or even below 1 $\mathrm{m}$ depth, and that these resources may be used by plants (Stone and Comerford, 1994). Numerous studies have shown that soil moisture can be equal to or higher in the subsoil than in the topsoil. The ratio of subsoil-to-topsoil moisture varies greatly, but is generally higher with larger evaporation and with access to ground water. Borchert (1994) reported a high de- pendence of water use and phenology on subsoil water availability for several multi-purpose trees in a tropical dry forest such as Albizia guachepele, Gliricidia sepium, Cordia alliodora and Gmelina arborea. This was more pronounced in areas that had drier surface soils in some seasons and access to subsoil water. In a persimmon tree orchard in Japan, tree growth and fruit yield depended greatly on subsoil water availability (Hase et al., 1988). In both cases, subsoil water use controlled tree crop performance. Less obvious than water availability are the amounts of subsoil nutrients available to plants and their role in tree crop production. Soil organic matter contents are usually higher at the topsoil and are responsible for the retention and release of nutrients. Also, nutrients added to soil by litterfall and fertilization usually accumulate at the topsoil. High precipitation and temperature lead to rapid mineralization and leaching, which transports nutrients down in the profile in many regions. These nutrients constitute an important resource for the cropping system but are usually percolating below the root zone of the tree. Trees may intercept percolating nutrients and act as a 'safety net' against excessive nutrient losses by leaching (Van Noordwijk et al., 1996). In some cases, however, adsorption of nutrients can also be considerable in the subsoil and retard or temporarily prevent leaching below the root zone. Cation adsorption has even been observed in the subsoil of acid soils, but may only affect seasonal dynamics of cation leaching (Matschonat and Matzner, 1995). Anion adsorption may be significant and large amounts of nitrate (Cahn et al., 1992) and sulfate (Manderscheid et al., 2000) can be temporarily stored in acid subsoils. An increasing number of results have recently become available which show large quantities of $\mathrm{NO}_{3}{ }^{-}$in subsoil layers under different trees and in different ecoregions. Buresh and Tian (1998) reported that $70-315 \mathrm{~kg} \mathrm{NO}_{3}{ }^{-}-\mathrm{N} \mathrm{ha}^{-1}$ are stored in subsoils (0.5-2 $\mathrm{m}$ depth) at various locations (158 plots) in western Kenya. This accumulation is a valuable resource especially in those soils and climates where available nutrient contents are low, leaching is high, and the soils are deeply weathered, such as in the humid tropics. Nitrate leaching can be very rapid under these climatic and edaphic conditions and nitrate was found to a depth of $5 \mathrm{~m}$ under four different tree crops in the central Amazon (Figure 1). Ammonium is usually concentrated near the topsoil and correlates well with total $\mathrm{N}$ and $\mathrm{C}$ contents. However, subsoil nitrate accumulation may also be of significance in temperate climates. Faby and Naumann (1986) reported high 
subsoil nitrate contents $\left(267 \mathrm{~kg} \mathrm{NO}_{3}{ }^{-}-\mathrm{N} \mathrm{ha}^{-1}\right.$ at $0.3-$ $0.9 \mathrm{~m}$ ) in a well-buffered loess soil of an apple orchard in Germany. Using a large database consisting of more than 20000 soil profiles (>90\% from the U.S.), Jobbágy and Jackson (2001) showed that available P and $\mathrm{K}$ were on average concentrated near the soil surface, whereas appreciable $\mathrm{Ca}, \mathrm{Mg}, \mathrm{NO}_{3}{ }^{-}$, and $\mathrm{SO}_{4}{ }^{2-}$ concentrations were found in the subsoil with higher nutrient stocks at 20-100 than 0-20 cm depth. For $\mathrm{Mg}$, this comparison also held when soil types were restricted to highly weathered Ultisols.

Indications exist that such subsoil nutrient resources can actually be used by tree crops and can be an important source of nutrients to plants. Sugar maple (Acer saccharum) was shown to recycle $\mathrm{Ca}$ from the subsoil (below $20 \mathrm{~cm}$ depth) to the surface and modeling demonstrated that a relatively small amount of $\mathrm{Ca}$ uptake in the deep soil is able to sustain high amounts of available $\mathrm{Ca}$ in the surface soil (Dijkstra and Smits, 2002). In Canada, Kowalenko (1996) reported a better correlation of subsoil mineral $\mathrm{N}$ at $0.3-0.6 \mathrm{~m}$ than surface mineral $\mathrm{N}$ with hazelnut $\mathrm{N}$ nutrition in some years. In several experiments in Kenya, legume fallow trees were shown to utilize subsoil nitrate to a depth of 2-4 m (Hartemink et al., 1996; Mekonnen et al., 1997).

The availability of water in the subsoil may also affect the utilization of subsoil nutrients and vice versa. In a nutrient-poor loamy soil in Nebraska, alfalfa developed roots to a depth of $2 \mathrm{~m}$ only if both nutrient and soil water were available (Fox and Lipps, 1955). Pockets of roots of this perennial were found only where both available $\mathrm{P}$ and $\mathrm{Ca}$ increased within buried A horizons and soil moisture was high near the water table. Similar dependencies should be valid for woody perennials, as well.

Under certain geological conditions, nutrient availability is higher at greater depth than at the topsoil due to nutrient release from the parent material. In their review, Stone and Kalisz (1991) list several published examples where nutrient contents were significantly higher in the subsoil at several meters depth than in the topsoil and could be exploited by trees such as $\mathrm{N}$ in shale, $\mathrm{P}$ from a phosphatic marl, and $\mathrm{K}$ in stratified deposits. Although these are extreme cases, most substrates are indeed not homogeneous and increasing nutrient availability with depth may occur in many situations. In the following I will discuss which factors may control subsoil resource use such as species properties, soil properties, and tree management.

\section{Subsoil root activity}

Root abundance of plants is usually highest at the topsoil (Canadell et al., 1996). Tree crops are not an exception and often have their maximum root length density in the first centimeters of soil or even in the litter layer. However, early reports have revealed that tree crops can also have roots at several meters depth, as shown for apple below $2.7 \mathrm{~m}$ in Wisconsin (Goff, 1897, cited in Stone and Comerford, 1994) or even below $4 \mathrm{~m}$ in Nebraska (Yocum, 1937). Some extreme cases have been reported where tree roots were found at 35-61 m depth (Stone and Kalisz, 1991). No account is possible from these types of assessments, however, about the relative distribution with depth, and they may therefore have limited value for the quantification of subsoil resource use.

In contrast to root abundance measured as the amount of root tips, unit weight, or length of live or dead roots per unit soil weight or volume, socalled 'root activity' measurements reflect the actual uptake of nutrients or water by roots. Several different approaches are available to assess root activity at different depths: such as plant uptake of applied radioisotopes (IAEA, 1975; Lehmann and Muraoka, 2001; Wahid, 2001); uptake of stable isotopes that were applied or occur naturally (Dambrine et al., 1997; IAEA, 1975; Lehmann and Muraoka, 2001; Plamboeck et al., 1999); and depletion of water (Wahid, 2001) or nutrients (Schroth et al., 2000).

Most isotopic techniques measure the foliar contents of a tracer applied to a certain depth. By comparing different trees that received a tracer application at different depths, the distribution of root activity can be calculated as the percentage uptake from one depth in relation to all other depths where the tracer was applied. Isotopic techniques give better estimates about the activity of roots than root abundance, but cannot determine absolute uptake from a specific soil depth. Rather, they give relationships between the uptakes from different depths.

Natural occurrences of unusual elements or natural isotope discrimination at depth can be used as indicators for subsoil nutrient uptake but are limited to few sites. Furthermore, they would not yield uptake profiles and therefore provide only a snapshot as to which depth the roots definitely reach. An example is the $\mathrm{U}$ uptake by Juniperus monosperma and Pinus edulis from coal-beds at $20 \mathrm{~m}$ depth (Cannon and Starett, 1956, cited in Stone and Kalisz, 1991) or the use of 
Root activity distribution [\%]

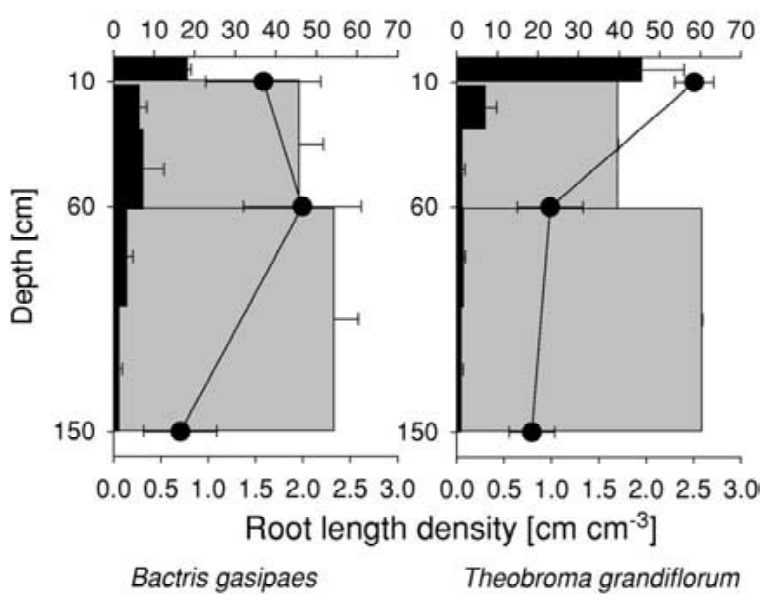

Figure 2. Root activity distribution and life root length density $(<1$ $\mathrm{mm}$ ) under two fruit trees in the central Amazon at 6 and 4 years after planting, respectively; the black bars indicate root length; the lines indicate the measured root activity at three depths $(10,60$, $150 \mathrm{~cm}$ ), the gray bars are the proportions of root activity between $10-60$ and $60-150 \mathrm{~cm}$ depth obtained by multiplication of the average activity (linear interpolation) between two application depths and the depth of the soil layer; root activity patterns shown as a mean of tracer applications at the end of the dry (using with both ${ }^{32} \mathrm{P}$ and ${ }^{15} \mathrm{~N}$ ) and wet (double-labeling of ${ }^{32} \mathrm{P}$ and ${ }^{33} \mathrm{P}$ ) season; root length density determined by destructive sampling of all live roots present, but it can be assumed that almost all roots derived from the respective tree species (activity $(N=3)$ and length density $(N=2)$ recalculated from Lehmann et al. (2001) and Haag (1997), respectively; means and standard errors).

${ }^{87} \mathrm{Sr}$-to- ${ }^{86} \mathrm{Sr}$ ratios for trees in Spain (Dambrine et al., 1997) and French Guiana (Poszwa et al., 2002).

The depletion of total or available nutrient contents can rarely be used for an assessment of root activity because nutrient export by leaching from the studied soil depth as well as nutrient input by leaching, mineralization, and weathering are commonly not quantified. Some estimates can be done in situations where several of these processes can be excluded: such as when nutrients are immobile in soil, not present in other than the measured form, or where leaching can be neglected. Accompanying measurements of root abundance may help to support the conclusions (Schroth et al., 2000). The same is true for root activity estimates using soil water contents or suction, although the sources and sinks of water can be better controlled in the subsoil.

Root activity measurements by IAEA (1975) revealed that many studied trees took up more resources per unit soil depth from the topsoil than the subsoil. Some exceptions exist where root activity was higher at 20-40 $\mathrm{cm}$ than $10 \mathrm{~cm}$ depth (IAEA, 1975). For example, peach palm (Bactris gasipaes) had a higher uptake of applied tracers from 60 than $10 \mathrm{~cm}$ depth (Figure 2). These calculations disregard the fact that even if the uptake from a soil layer with a thickness of only $10 \mathrm{~cm}$ is 10 times higher than the uptake from a soil layer with a thickness of $1 \mathrm{~m}$, the total uptake is the same from both layers. Therefore, the relative contribution of the soil layer at a depth of $60-150 \mathrm{~cm}$ to total uptake was higher than the one at $10-60 \mathrm{~cm}$ for both tree crops (Figure 2). Even T. grandiflorum with an uptake of only $19 \%$ at $150 \mathrm{~cm}$ depth compared to 10 and $60 \mathrm{~cm}$ depths took up more resources from 60 $150 \mathrm{~cm}(60 \%)$ than $10-60 \mathrm{~cm} \mathrm{(40 \% ).} \mathrm{Considering} \mathrm{the}$ large amount of plant-available nitrate present in the subsoil at the same site (Figure 1), this root activity distribution could lead to a significant $\mathrm{N}$ resource use from the subsoil.

In the example discussed above (Figure 2), the distribution of the length density of fine roots satisfactorily reflected the depth distribution of root activity averaged for the entire year. However, when root distribution was determined in different seasons, such as for coffee in Kenya (Figure 3), root mass distribution did not always match root activity distribution, which was found to be more sensitive to seasonal changes in soil water. Unfortunately, root length density data are not available from this experiment, but since the reported values are fine roots, the length density should behave reasonably similar to the mass. Similarly, guava root activity significantly increased in the subsoil during the dry season which was not reflected by the distribution of fine root mass $(<1.5 \mathrm{~mm}$ ) (Purohit and Mukherjee, 1974). Root activity of orange trees was measured using ${ }^{32} \mathrm{P}$ applications in approximately 3-week intervals during one year and large differences and rapid changes were found between seasons with one order of magnitude difference (Iyengar and Shivananda, 1990). Short-term changes of the uptake distribution of water and nutrients, which can be quite large and rapid, cannot be detected by root sampling. Root activity measurements can yield a more dynamic picture.

Root activity and nutrient uptake commonly depend strongly on soil water contents, and this has been extensively shown for annual crops (e.g., Cox and Barber, 1992). Due to the longer life cycle of woody perennials than annuals, the disparity between root abundance and activity may be even larger for tree than field crops. The question remains, whether root abundance is an adequate time integral of root 


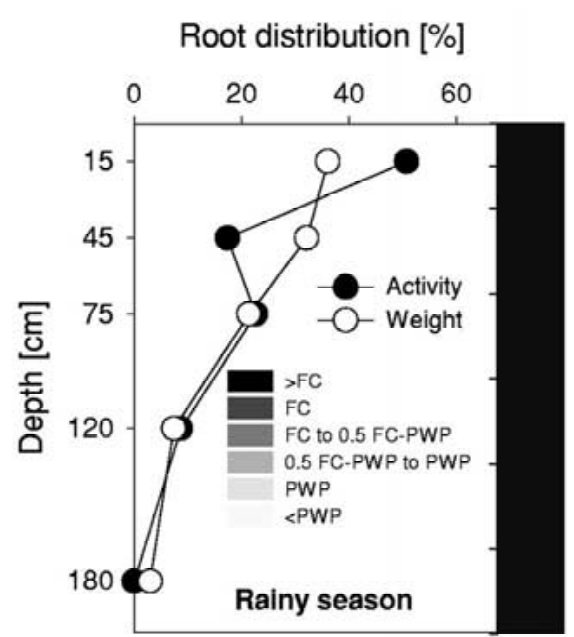

Root distribution [\%]

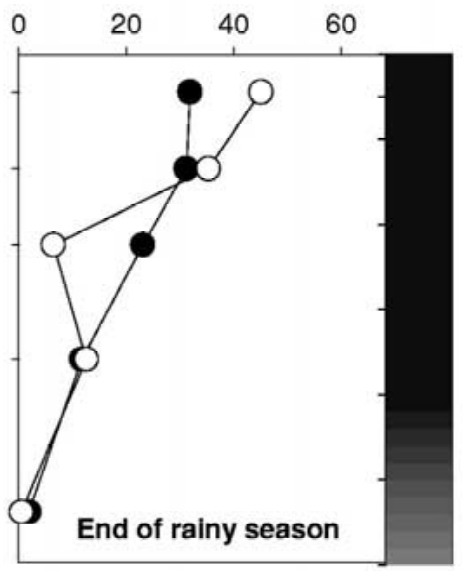

Root distribution [\%]

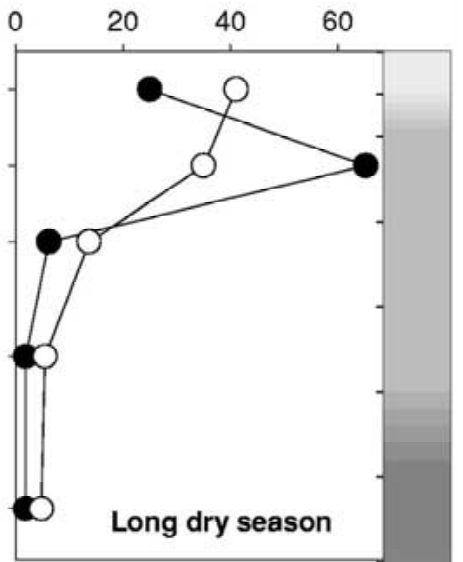

Figure 3. Root activity and root mass (fine roots $<2.5 \mathrm{~mm}$ diameter) distribution of coffee (Coffea arabica) in dry and wet seasons at different soil water contents (FC field capacity; PWP permanent wilting point) ( $N=4$ for root data, $N=2$ for water data; Huxley et al., 1974).

activity. In most cases, root activity distribution is not static and neither is root abundance. When the root system is in equilibrium, seasonal fluctuations of root abundance distributions of trees may lag behind root activity changes but may have no large impact on interpretations of uptake patterns. This is often the case in mature and undisturbed forests or grasslands with little seasonal weather changes. In tree-based cropping systems, however, root systems are more dynamic and react not only to seasonal changes of soil moisture and temperature but also to tree and soil management. Additionally, the root systems expand during maturation. Under these circumstances, root abundance may not represent root activity well and assessments of root activity distributions are more suitable.

\section{Spatial and temporal heterogeneity of root activity distributions}

Root distribution is laterally not homogeneous, as roots seek areas where they can grow easily and frequently follow water and nutrients in the soil. Cracks in parent rocks (Dell et al., 1983), soft spots in hard pans, and old root channels are preferred rooting areas (Van Noordwijk et al., 1991). In root channels at 15-40 $\mathrm{m}$ depth of Eucalyptus marginata forests in southwestern Australia, exchangeable $\mathrm{Ca}$ of the granitic clay was increasingly depleted with proximity to the root surface (Dell et al., 1983). These root activity patterns pose large challenges to the assessment of the contribution of the subsoil to total nutrient and water uptake. The suggested tracer studies may not be adequate under these circumstances, as uptake and solute flow patterns may correlate under preferential rooting and flow. Van Noordwijk et al. (1991) found an advantage for crop roots to use old root channels since $\mathrm{N}$ flows passed through these channels and $\mathrm{N}$ could be more easily taken up by the roots. Modeling approaches may help to better understand the root activity distribution under spatially very heterogeneous soil conditions.

Seasonal differences in resource distribution in the soil also control root activity distributions. This was frequently demonstrated for soil water uptake, which closely follows the water distribution in soil. In dryland Kenya, tree root activity had the capacity to switch rapidly from one part of the root system to another in response to soil moisture availability determined by sap flow measurements (Odhiambo et al., 1999). This information could not be obtained from root length densities in the same study. But also the uptake of ${ }^{32} \mathrm{P}$ by cacao (Theobroma cacao L.) was shown to increase at $30 \mathrm{~cm}$ depth in relation to the overlying soil during the dry season (Ahenkorah, 1975). Lemon trees also had a higher root activity at greater depths (measured to a depth of $60 \mathrm{~cm}$; Chandra et al., 1979) as well as coffee (measured to a depth of $180 \mathrm{~cm}$; Huxley et al., 1974) during the dry season compared to the wet season. Several other studies confirm these results (Iyengar and Shivananda, 1990; Purohit and Mukherjee, 1974). The seasonal changes are controlled by soil water availability as demonstrated for coffee in Kenya (Figure 3). During the rainy season with high 
soil water availability throughout the soil profile, root activity was highest near the topsoil. In the dry season, however, topsoil water availability was low and root activity decreased at $15 \mathrm{~cm}$ depth (Figure 3). Apart from lower mass flow and diffusion, dry soil conditions may also cause root death thus reducing root activity (Forde, 1972).

Low topsoil root activity induced by lack of moisture should result in a lower uptake of topsoil nutrients. In this case, it is important to know if sufficient subsoil nutrients are available to the tree for sustained growth throughout the drier period. Even in a sandy soil with low subsoil nutrients, the nitrate, $\mathrm{Ca}, \mathrm{K}$, and $\mathrm{Mg}$ concentrations of the xylem sap of sinker roots of Banksia prionotes were still 40-60\% of those found in the lateral roots during the dry season (Jeschke and Pate, 1995). Banksia is a fast-growing tree of the open woodland of southwestern Australia with a dimorphic root system forming deep roots to the water table and at the same time superficial roots. Since the sap flow in sinker roots was supposedly high compared to that in the lateral roots during the dry season, the total contribution of the subsoil to tree nutrition was significant during dry periods.

\section{Biophysical factors affecting subsoil root activity by trees}

\section{Tree species}

The ability to access subsoil resources is driven by both the availability of these resources, the tree and soil management, as well as the physiological characteristics of the tree species and cultivars. Adaptation of species for accessing subsoil resources vary and depend on their specific strategies to cope with nutrient and water stresses.

Figure 4 shows the cumulative root activity distribution with depth for the trees listed in Table 1. Few data of root activity distribution are available with measurements of more than four depths extending deeper than $100 \mathrm{~cm}$. Although many studies show similar root activity in the first and second depths that were analyzed, an assessment of root activity deeper in the profile was sometimes not conducted. The reason may often have been the need for a large number of plots with sufficient distances to each other. Other than root observations using core sampling, trenches or rhizotrons where all depths can be investigated at the same tree or plot, root activity measurements require a new plot for each depth. Sufficient distance

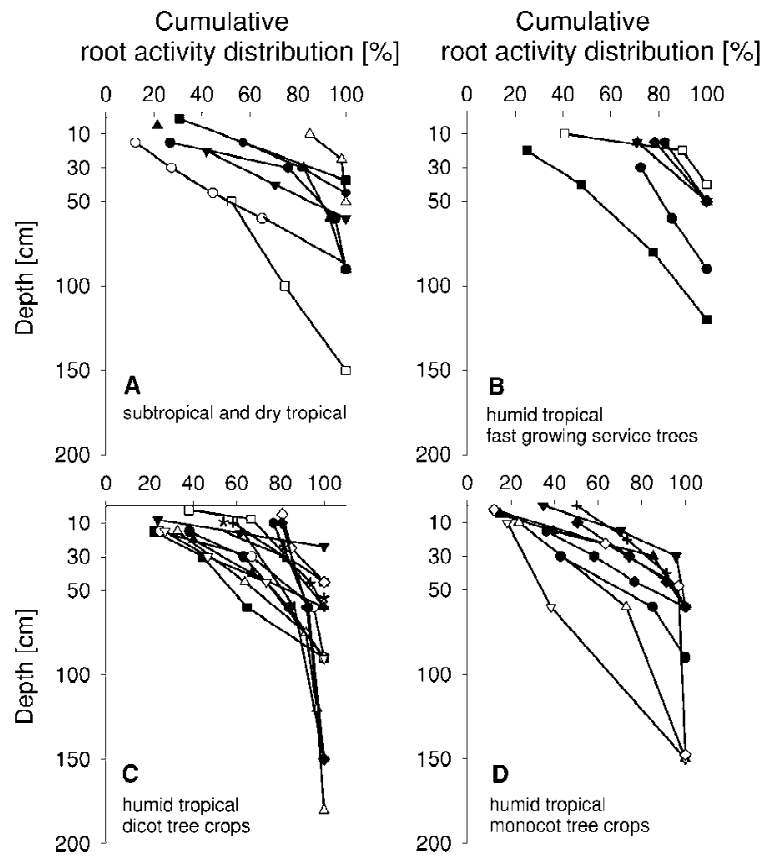

Figure 4. Cumulative root activity with soil depth for 38 tree crops listed in Table 1. Vertical distribution given as the mean of all distances from the trunk, from all multiple measurements and seasons given in the studies.

must be maintained between these subplots to exclude cross contamination, because lateral root activity can be considerable as shown for oil palm in Ivory Coast (IAEA, 1975).

In order to quantitatively compare root activity distribution a model for vertical root distribution was fitted to the data derived from the theoretical model of Gale and Grigal (1987), with the modification of using a maximum activity constant $A_{\max }$ :

$$
\text { Activity }=A_{\max }\left(1-k^{\text {depth }}\right)
$$

$A_{\max }$ was used because very few data sets are available which assess root activity to greater depths. Only data that included three or more measured depths and even spacing between depths were used for modeling. The regression constant $k$ is a measure of the relative rooting depth, higher values indicating deeper rooting (Table 1). The constant was used to calculate root activity distributions with a maximum $\left(A_{\max }\right)$ of $100 \%$ (Figure 5) and the depth that comprises $75 \%$ of the total root activity by a given tree (Table 1 ). This model also recognizes the specific dependency of total uptake on the volume from where resources are taken up as discussed earlier (Figure 2). The values obtained from such a model can be included in modeling exercises of nutrient and water cycling. 
Table 1. Tree species, site description and regressions for root activity distributions shown in Figure 4; regressions were not performed for data sets with two depths or less and with uneven spaces between depths of application

\begin{tabular}{|c|c|c|c|c|c|c|c|c|c|}
\hline $\begin{array}{l}\text { Graph } \\
\text { and } \\
\text { symbol }\end{array}$ & Tree species & $\begin{array}{l}\text { Age } \\
\text { (years) }\end{array}$ & Country & Soil type & $\begin{array}{l}\text { Climate* } \\
\left(\mathrm{mm}\left({ }^{\circ} \mathrm{C}\right)\right)\end{array}$ & $k \dagger$ & $\begin{array}{l}\text { Depth of } \\
75 \% \text { root } \\
\text { activity } \\
(\mathrm{cm})\end{array}$ & $r^{2}$ & $\begin{array}{l}\text { Source } \\
\text { (source for climate data) }\end{array}$ \\
\hline $\mathrm{CE}$ & Theobroma cacao & 20 & Ghana & Oxisol & $1341(25.8)$ & 0.873 & 10.2 & 0.924 & $\begin{array}{l}\text { Ahenkorah (1975) } \\
\text { (Ho, Kumasi })\end{array}$ \\
\hline $\mathrm{D} \bullet$ & Cocos nucifera & 9 & India & Oxisol & $683(27.8)$ & 0.988 & 113.9 & 0.971 & $\begin{array}{l}\text { Anilkumar and Wahid } \\
\text { (1988) }\end{array}$ \\
\hline A $\bullet$ & Citrus reticulata & 5 & India & Alfisol & $1607(13.3)$ & 0.971 & 46.3 & 0.910 & $\begin{array}{l}\text { Badiyala et al. (1992) } \\
\text { (Shimla } \ddagger)\end{array}$ \\
\hline $\mathrm{C} \bullet$ & Mangifera indica & 18 & India & n.a. & $706(25.0)$ & 0.971 & 47.3 & 0.991 & $\begin{array}{l}\text { Bojappa and Singh (1974) } \\
\text { (New Delhi } \ddagger)\end{array}$ \\
\hline A $\boldsymbol{\nabla}$ & Citrus limon & 6 & India & Clay loam & n.a. & 0.990 & 135.2 & 0.995 & Chandra et al (1979) \\
\hline $\mathrm{C}$. & Citrus paradisi & 20 & India & $\begin{array}{l}\text { Sandy } \\
\text { loam }\end{array}$ & n.a. & 0.983 & 80.9 & 0.974 & Dhandar and Singh (1989) \\
\hline A E & Olea europaea & 20 & Spain & Loam & irrig. (18.2) & 0.981 & 71.9 & 0.995 & Fernandez et al. (1991) \\
\hline $\mathrm{B} \boldsymbol{\Delta}$ & $\begin{array}{l}\text { Acacia } \\
\text { auriculiformis }\end{array}$ & 5 & India & Oxisol & $2570(27.1)$ & - & - & - & George et al. (1996) \\
\hline $\mathrm{B} \boldsymbol{\nabla}$ & $\begin{array}{l}\text { Casuarina } \\
\text { equisetifolia }\end{array}$ & 5 & India & Oxisol & $2570(27.1)$ & - & - & - & George et al. (1996) \\
\hline $\mathrm{B} \bullet$ & $\begin{array}{l}\text { Leucaena } \\
\text { leucocephala }\end{array}$ & 5 & India & Oxisol & $2570(27.1)$ & - & - & - & George et al. (1996) \\
\hline $\mathrm{B} \bullet$ & Ailanthus triphysa & 5 & India & Oxisol & $2570(27.1)$ & - & - & - & George et al. (1996) \\
\hline $\mathrm{C} \Delta$ & Coffea arabica & 9 & Kenya & Alfisol & $1500(18)$ & 0.976 & 56.7 & 0.983 & $\begin{array}{l}\text { Huxley et al. (1974) } \\
\text { (estimated) }\end{array}$ \\
\hline $\mathrm{D} \boldsymbol{\nabla}$ & Musa sp. & 2 & Uganda & Ultisol & n.a. & 0.922 & 17.1 & 0.543 & IAEA (1975) \\
\hline $\mathrm{A} \boldsymbol{\Delta}$ & Citrus sp. & 30 & Spain & Inceptisol & n.a. & - & & - & IAEA (1975) \\
\hline $\mathrm{C}+$ & Citrus sp. & 12 & Taiwan & $\begin{array}{l}\text { Sandy } \\
\text { loam }\end{array}$ & n.a. & - & & & IAEA (1975) \\
\hline $\mathrm{C} \nabla$ & Coffea arabica & 8 & Colombia & n.a. & $2554(20.8)$ & 0.984 & 86.0 & 0.984 & $\begin{array}{l}\text { IAEA (1975) } \\
\text { (Chinchina } \ddagger)\end{array}$ \\
\hline $\mathrm{D} \bullet$ & Cocos nucifera & 60 & Philippines & $\begin{array}{l}\text { Black silty } \\
\text { loam }\end{array}$ & $2051(27.7)$ & 0.986 & 99.0 & 0.985 & $\begin{array}{l}\text { IAEA }(1975) \\
(\text { Manila } \ddagger)\end{array}$ \\
\hline $\mathrm{D} \diamond$ & Cocos nucifera & 50 & Sri Lanka & $\begin{array}{l}\text { Sandy } \\
\text { loam }\end{array}$ & n.a. & - & - & - & IAEA (1975) \\
\hline $\mathrm{D} \diamond$ & Elaeis guianensis & 7 & Ivory coast & $\begin{array}{l}\text { Sandy } \\
\text { clay }\end{array}$ & n.a. & - & - & - & IAEA (1975) \\
\hline $\mathrm{D}+$ & Elaeis guianensis & 7 & Malaysia & $\begin{array}{l}\text { Sandy } \\
\text { clay loam }\end{array}$ & $2620(27)$ & 0.939 & 22.0 & 0.987 & IAEA (1975) \\
\hline A $\Delta$ & Citrus aurantifolia & $6-7$ & India & Alfisol & $909(23.8)$ & - & - & - & $\begin{array}{l}\text { Iyengar and Keshava } \\
\text { Murthy (1987) }\end{array}$ \\
\hline $\mathrm{A} \bigcirc$ & Vitis vinifera & 7 & India & Alfisol & $909(23.8)$ & 0.998 & 1210 & 0.929 & Iyengar et al. (1989) \\
\hline $\mathrm{A} \nabla$ & Citrus sinensis & n.a. & India & Alfisol & $909(23.8)$ & 0.957 & 31.2 & 0.989 & $\begin{array}{l}\text { Iyengar and Shivananda } \\
\text { (1990) }\end{array}$ \\
\hline $\mathrm{B} \odot$ & $\begin{array}{l}\text { Artocarpus } \\
\text { hirsutus }\end{array}$ & 8.5 & India & Oxisol & $2570(27.1)$ & 0.957 & 31.5 & 0.884 & Jamaludheen et al. (1997) \\
\hline B E & Erythrina indica & 6.5 & India & Ultisol & $2570(27.1)$ & 0.929 & 75.5 & 0.982 & $\begin{array}{l}\text { Jayasree Sankar et al. } \\
\text { (1988) }\end{array}$ \\
\hline $\mathrm{C} \boldsymbol{\Delta}$ & Mangifera indica & 8 & India & Alfisol & $909(23.8)$ & 0.994 & 215.9 & 0.989 & Kotur et al. (1997) \\
\hline $\mathrm{C} \boldsymbol{\nabla}$ & Citrus karna & $5-6$ & India & n.a. & $706(25.0)$ & - & - & - & $\begin{array}{l}\text { Kurien et al. (1992a) } \\
\text { (New Delhi } \ddagger \text { ) }\end{array}$ \\
\hline
\end{tabular}


Table 1. Continued

\begin{tabular}{|c|c|c|c|c|c|c|c|c|c|}
\hline $\begin{array}{l}\text { Graph } \\
\text { and } \\
\text { symbol }\end{array}$ & Tree species & $\begin{array}{r}\text { Age } \\
\text { (years) }\end{array}$ & Country & Soil type & $\begin{array}{l}\text { Climate* }^{*} \\
\left(\mathrm{~mm}\left({ }^{\circ} \mathrm{C}\right)\right)\end{array}$ & $k \dagger$ & $\begin{array}{l}\text { Depth of } \\
75 \% \text { root } \\
\text { activity } \\
(\mathrm{cm})\end{array}$ & $r^{2}$ & $\begin{array}{l}\text { Source } \\
\text { (source for climate data) }\end{array}$ \\
\hline $\mathrm{C} \diamond$ & $\begin{array}{l}\text { Theobroma } \\
\text { grandiflorum }\end{array}$ & 6 & Brazil & Oxisol & $2600(26)$ & - & - & - & Lehmann et al. (2001) \\
\hline $\mathrm{D} \Delta$ & $\begin{array}{l}\text { Bactris gasipaes } \\
\text { (heart of palm) }\end{array}$ & 6 & Brazil & Oxisol & $2600(26)$ & - & - & - & Lehmann et al. (2001) \\
\hline $\mathrm{D} \nabla$ & $\begin{array}{l}\text { Bactris gasipaes } \\
\text { (fruit) }\end{array}$ & 6 & Brazil & Oxisol & $2600(26)$ & - & - & - & Lehmann et al. (2001) \\
\hline $\mathrm{C} \bullet$ & $\begin{array}{l}\text { Bertholletia } \\
\text { excelsa }\end{array}$ & 6 & Brazil & Oxisol & $2600(26)$ & - & - & - & Lehmann et al. (2001) \\
\hline $\mathrm{C}$ & Bixa orellana & 6 & Brazil & Oxisol & $2600(26)$ & - & - & - & Lehmann et al. (2001) \\
\hline C B & Psidium guajava & 12 & India & n.a. & $706(25.0)$ & 0.993 & 200.2 & 0.976 & $\begin{array}{l}\text { Purohit and Mukherjee } \\
\text { (1974) }\end{array}$ \\
\hline $\mathrm{C} \diamond$ & Coffea arabica & 7 & Costa Rica & Ultisol & $2600(23)$ & - & - & - & Saiz del Rio et al. (1961) \\
\hline $\mathrm{D} \boldsymbol{\Delta}$ & Musa sp. & 0.4 & India & Oxisol & $2570(27.1)$ & - & - & - & Sobhana et al. (1989) \\
\hline A B & Vitis sp. & 25 & USA & Loam & n.a. & - & - & - & Ulrich et al. (1947) \\
\hline B B & Gliricidia sepium & n.a. & India & Oxisol & $3175(27.5)$ & 0.990 & 142.2 & 0.999 & $\begin{array}{l}\text { Vasu et al. (1994) } \\
\text { (Kozhikode } \ddagger \text { ) }\end{array}$ \\
\hline $\mathrm{C}^{*}$ & $\begin{array}{l}\text { Anacardium } \\
\text { occidentale }\end{array}$ & 20 & India & Ultisol & $2570(27.1)$ & 0.994 & 228.9 & 0.953 & Wahid et al. (1989a) \\
\hline $\mathrm{C} \bigcirc$ & Theobroma cacao & 7 & India & Oxisol & $2570(27.1)$ & 0.976 & 56.6 & 0.943 & Wahid et al. (1989b) \\
\hline
\end{tabular}

n.a. - not available.

* Mean annual rainfall and temperature.

$\dagger$ Regression constant $k$ derived from the equation Activity= $A_{\max }\left(1-k^{\text {depth }}\right)$.

\$ Rainfall data from the Global Historical Climatic Network, Oak Ridge Laboratory.

From these calculations the variation of root activity distributions becomes obvious. Most of the root activity (75\%) may be confined to the top $10 \mathrm{~cm}$ such as for cacao in Ghana, but may also reach as deep as $216 \mathrm{~cm}$ for mango in India (Table 1). Thus, more than $90 \%$ of the cumulative root activity was below $10 \mathrm{~cm}$ depth and 40-60\% even below $1 \mathrm{~m}$ depth for some tree crops (Figure 5). Such deep root activity is important for resource acquisition. However, only few trees showed root activity reaching similarly deep.

Palm trees did not have a different activity distribution than dicot trees. Shaded tree crops such as coffee and cacao tended to have a more shallow root activity than tree crops that are usually grown in monoculture including orange, mango or guava. This may be an effect of the cropping system, the tree species or the genotype. The deepest root activity was noted for fruit trees.

No obvious factor was obtained from the cited publications to explain the large variation of root activity distributions. Mango had both a comparatively shallow root activity, as in the example from Bojappa and
Singh (1974), and a very deep one as shown by Kotur et al. (1997). Annual rainfall or mean air temperature did not correlate well with root activity distributions $\left(r^{2}<0.15 ; P<0.2\right.$ using rainfall; $P>0.2$ using temperature). Correlations for $A_{\max }$ were negative for rainfall and positive for temperature indicating a tendency towards deeper rooting with higher temperatures and lower rainfall.

Most of the studies were done on deeply weathered oxisols. No information could be drawn from the publications on which site properties controlled root activity distributions. Site characteristics that were unavailable from the reviewed studies could potentially explain the differences (e.g., soil texture, density, rock), but this seemed unlikely in view of the soil descriptions that generally indicated deep soils (oxisols and ultisols, Table 1) without properties restricting vertical root growth.

The calculation of the model allowed for a comparison of the regression constants with the values obtained by Jackson et al. (1996) for root masses from terrestrial biomes. In their work, the regres- 


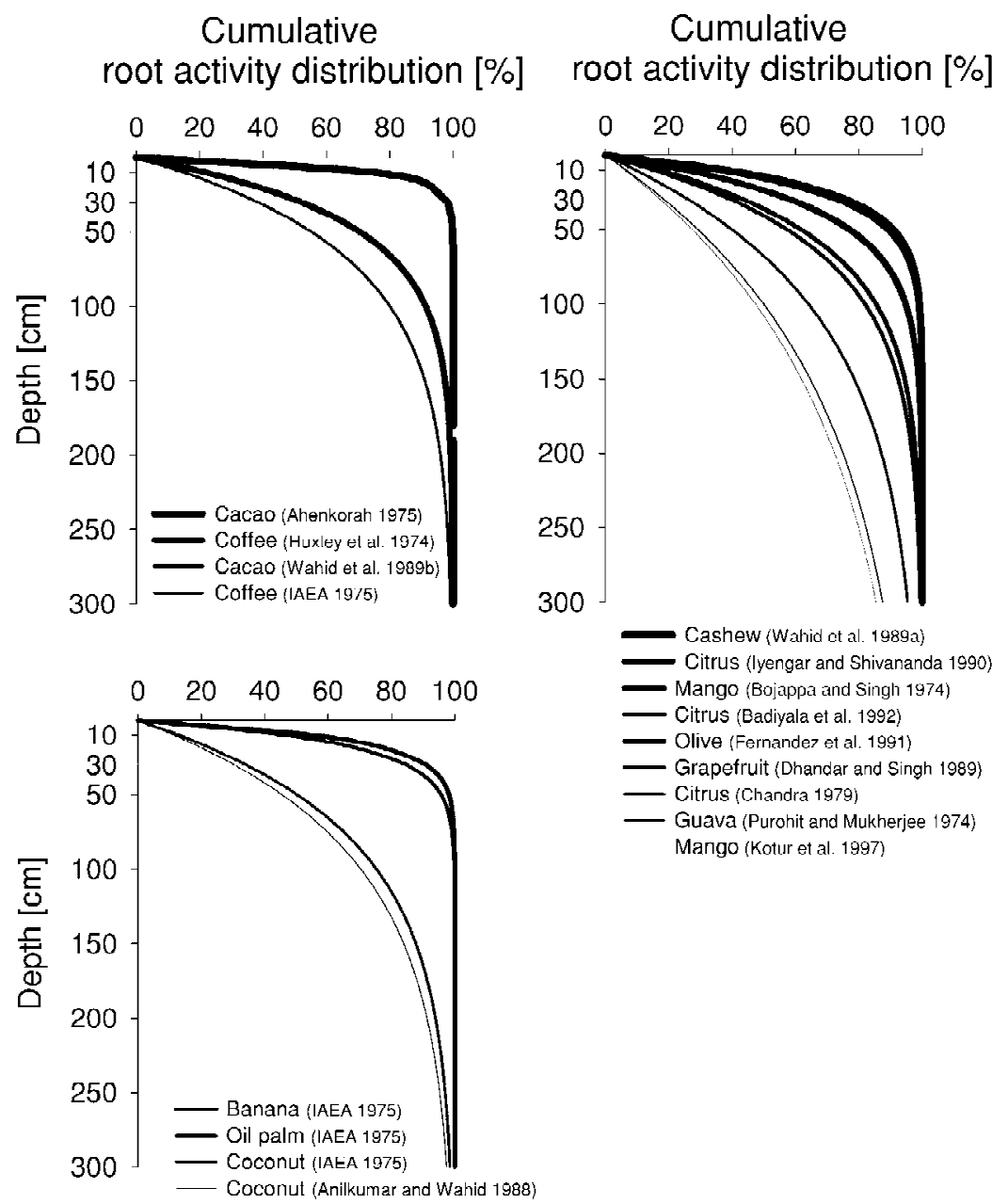

Figure 5. Cumulative root activity with soil depth for those tree crops listed in Figure 4 with more than three data points. Calculations described in the text.

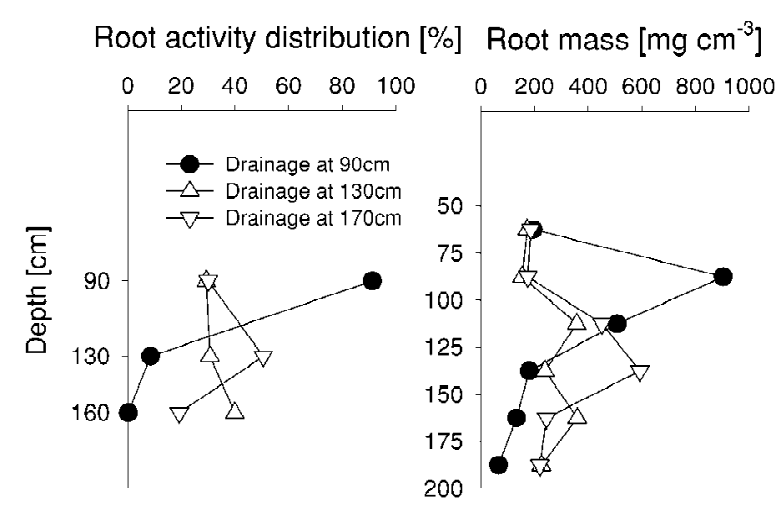

Figure 6. Root activity distribution and root length density of 7-year-old apple trees as affected by drainage depth using lysimeters $\left(240 \mathrm{~cm}\right.$ high and $150 \mathrm{~cm}$ wide); root activity measured with ${ }^{35} \mathrm{~S}$ and ${ }^{32} \mathrm{P}(N=2$; Hansen, 1974). sion constant ranged from 0.914 for tundra vegetation indicating very shallow root systems to deep root systems with $k$ values of $0.976,0.975$, and 0.972 for temperate coniferous forests, desert vegetation, and tropical grassland savanna, respectively. The variation of root activity distributions found in the present study is higher than the differences between biomes assessed by Jackson et al. (1996). Therefore, tree-specific variations were larger than site- and climate-specific variations for the sites investigated in the compiled studies. The tree crops show a sufficiently flexible subsoil root system to explore subsoil resources. If subsoil root activity is desirable for optimal use of nutrients and water, it is possible to find trees that will perform this function. Different rootstocks have shown significantly different root activity distributions with 
depth (Kurien et al., 1992b) that provides additional management options.

The second observation is that the $k$ value and therefore the depth of root activity is generally very large compared to the root mass distributions found by Jackson et al. (1996). This is even more surprising when considering that root activity was mostly measured on young tree crops (a few years to not older than 60 years) in comparison with mature forest biomes included in the studies reviewed by Jackson et al. (1996). It may be hypothesized that root activity stretches deeper into the subsoil than root mass may suggest. Such an observation would emphasize the importance of the subsoil for resource use. Since there are very few data which allow the comparison between root activity and root mass or length distribution, this needs to be verified in future studies.

\section{Soil properties}

Subsoil root activity and resource use not only depend on the resource supply and tree species as discussed above but also on soil properties that may reduce root growth. These properties can be mechanical or chemical, such as compacted soil horizons, lack of oxygen, or acidity, which is well known. The challenge is to link soil properties to resource use in the subsoil, which has only rarely been demonstrated.

Ground water is not only a resource for water uptake by trees but also restricts root activity due to a lack of oxygen in submerged horizons. Apple trees were shown to have a more shallow root activity measured with ${ }^{35} \mathrm{~S}$ and ${ }^{32} \mathrm{P}$ when the ground water was higher (Figure 6). Seventy centimeters below the drainage depth of $90 \mathrm{~cm}$, root activity approached zero. At the same depth a considerable amount of roots could be found as shown by the root mass determinations (Figure 6). Roots may be present in submerged soil horizons but do not take up significant amounts of water or nutrients.

On an artificially compacted soil with little access of tree roots to the subsoil, Sheriff and Nambiar (1995) observed better growth of Pinus radiata than on an uncompacted soil or a subsoil that had been perforated. Access to subsoil water, as well as to subsoil nutrients was responsible for the growth increase leading to lower water stress and improved plant nutrition. Soil water contents were higher in the subsoil of compacted $\left(0.046 \mathrm{~m}^{3} \mathrm{~m}^{-3}\right)$ than uncompacted soils $(0.032$ $\mathrm{m}^{3} \mathrm{~m}^{-3}$; difference significant at $P<0.05$ ). The trees showed higher foliar P contents when they had ac- cess to the subsoil. Restricted convective and diffusive solute transport to the root surface was not responsible for the lower nutrient uptake from the topsoil of compacted soils, because topsoil water contents were not significantly different in uncompacted and compacted soils $\left(0.017\right.$ and $0.016 \mathrm{~m}^{3} \mathrm{~m}^{-3}$, respectively, during the dry summer and autumn months; Sheriff and Nambiar, 1995). Therefore, the subsoil can not only provide valuable water resources, but also nutrient resources for tree growth.

Acidity also significantly restricts root growth in the subsoil and therefore limits shoot growth. Pecan seedlings (Carya illinoensis (Wang.) K. Koch) had a $64 \%$ higher taproot growth rate in the subsoil when the $\mathrm{pH}$ was increased by liming from 5.1 to 6.5 at $16-46$ $\mathrm{cm}$ depth (White, 1982). Unfortunately, no information is available on how root activity of trees is reduced by acid subsoils. It can be assumed that root activity in an acid subsoil is even lower than root abundance may suggest, similar to the effect of water logging, because root growth decreases after growing into an acid subsoil due to an inhibition of cell division after contact with $\mathrm{Al}$ in soil (Marschner, 1986).

\section{Tree management and root activity distribution}

Tree management can have important effects on the depth distribution of roots in tree-based cropping systems such as pruning, planting density, fertilization, tillage (Lehmann, 2002) or irrigation (Fernandez et al., 1991). However, very little information is available about the management effects on vertical root activity patterns. Pruning 6-year-old peach palm (Bactris gasipaes) twice per year for the production of heart of palm decreased the relative root activity at 1.5 m (Lehmann et al., 2001). A shallower root system and less subsoil roots after shoot pruning was also found from destructive root sampling in several studies (e.g., Peter and Lehmann, 2000; Van Noordwijk and Purnomosidhi, 1995). This knowledge has important implications for tree management. Shoot pruning may be done less frequently or with lower intensity to maintain high subsoil root activity if water or nutrient supply from the subsoil is important.

Soil amendments significantly affect root activity. Drip irrigation was reported to increase root density of olive trees at the topsoil in $0-0.2 \mathrm{~m}$ by more than $60 \%$, whereas under rain-fed conditions, roots were evenly distributed or even higher in the subsoil to a depth $1.5 \mathrm{~m}$ (Fernandez et al., 1991). Uptake of ${ }^{32} \mathrm{P}$ 
injected at different depths revealed that also at $1.5 \mathrm{~m}$ depth, irrigated trees had a significant root activity. Increasing the water supply at the topsoil reduced but did not eliminate subsoil root activity of olive trees. Higher root activity by coconut at $0.3 \mathrm{~m}$ depth than at the topsoil was induced by application of fertilizers in a soil basin $25 \mathrm{~cm}$ deep around the trees (Wahid et al., 1993). On the other hand, fertilizer placement has to recognize root activity distributions. ${ }^{32} \mathrm{P}$ applied to grape vines at $38 \mathrm{~cm}$ depth was more than double the uptake from surface applied P (Ulrich et al., 1947). Fertilization of maple trees to alleviate Mn deficiency on alkaline soils was more effective when applied at $0.3 \mathrm{~m}$ depth than at the soil surface (Messenger and Hruby, 1990). Foliar Mn levels significantly increased when $\mathrm{MnSO}_{4}$ together with sulfuric acid was applied at $0.3 \mathrm{~m}$ depth, whereas no improvement was noted when the same amount was applied on the soil surface.

When subsoil acidity restricts vertical root penetration, the application of lime or gypsum can decrease Al toxicity and increase the $\mathrm{pH}$ (Sumner, 1995) to allow for root activity and nutrient uptake from acid subsoils (Carvalho and Raij, 1997). Lime applications alone usually did not improve subsoil chemical properties even if they were incorporated into the subsoil (Farina et al., 2000; Pavan et al., 1987). Apple had a higher fruit yield, biomass production and $\mathrm{Ca}$ nutrition due to higher root length densities, lower exchangeable $\mathrm{Al}$ and higher $\mathrm{Ca}$ contents in the subsoil after application of phosphogypsum to an oxisol in Brazil (Pavan et al., 1987). Farina et al. (2000) showed that gypsum applied together with lime significantly reduced subsoil acidity only after 6 years. The amelioration of subsoil acidity was much slower in less intensely weathered soils and under low rainfall (Farina et al., 2000) than in the highly weathered oxisols of Brazil (Ritchey et al., 1995). Even 16 years after gypsum application, the amelioration of subsoil acidity was still ongoing in an ultisol (Toma et al., 1999). These results indicate that subsoil root activity can be significantly increased by the application of both gypsum and lime for tree crops with long cropping cycles, but long-term effects were not studied in tree-based cropping systems until now.

The influence of cropping strategies such as intercropping trees with other trees or crops on subsoil root activity and root systems was discussed by Wahid (2001) and Schroth (1995, 1999), respectively, and will not be covered here.

\section{Conclusions}

Despite the often low relative root activity in the subsoil compared to the topsoil per unit soil, the large volume of subsoil represents an important resource for nutrient and water uptake by tree crops. More results become available which recognize the importance of the subsoil not only for water but also for nutrient uptake. Activity measurements were necessary to determine short-term dynamics of plant uptake, subsoil resource use with uneven depth distribution of resources or with soil properties restricting rooting depth (e.g., compaction, water logging, acidity) which cannot be assessed by root abundance. The obtained variations of root activity profiles ranging from very shallow root activity to very deep ones emphasize the need for a better understanding of the factors controlling subsoil resource use. The demonstrated flexibility of the root systems is seen as an opportunity for soil and tree management to manipulate subsoil resource use. More experiments on root activity in the subsoil are required using sufficient depth increments to relative activities of less than $5 \%$. Additional information need to be assessed such as soil water regimes, and soil physical and chemical properties in order to be able to conclusively link subsoil root activity to resource use. The environmental hazards of radioisotopes are recognized and therefore stable isotope techniques need to be developed to allow a wider applicability.

\section{Acknowledgements}

The assistance of Dr. Mohan Kumar in compiling the environmental data for a portion of the cited works is gratefully acknowledged. Mary-Ellen Niederhofer's help in gathering the references for this contribution is much appreciated.

\section{References}

Ahenkorah Y 1975 Use of radio-active phosphorus in determining the efficiency of fertilizer utilization by cacao plantation. Plant Soil 42, 429-439.

Anilkumar K S and Wahid P A 1988 Root activity pattern of coconut palm. Oleagineux 43, 337-340.

Badiyala S D, Pawasthi R P A and Anjan Kalia 1992 Root activity in kinnow mandarin (Citrus reticulata) using ${ }^{32} \mathrm{P}$ in submontane Himalayan region of India. Indian J. Agric. Sci. 62, 751-757.

Bojappa K M and Singh R N 1974 Root activity of mango by radiotracer technique using ${ }^{32} \mathrm{P}$. Indian J. Agric. Sci. 44, 175-180. 
Borchert R 1994 Soil and stem water storage determine phenology and distribution of tropical dry forest trees. Ecology 75, 14371449.

Buresh J J and Tian G 1998 Soil improvement by trees in subSaharan Africa. Agrofor. Syst. 38, 51-76.

Cahn M D, Bouldin D R and Cravo M S 1992 Nitrate sorption in the profile of an acid soil. Plant Soil 143, 179-183.

Canadell J, Jackson R B, Ehleringer J R, Mooney H A, Sala O E and Schulze E D 1996 Maximum rooting depth of vegetation types at the global scale. Oecologia 108, 583-595.

Carvalho M C S and van Raij B 1997 Calcium sulphate, phosphogypsum and calcium carbonate in the amelioration of acid subsoils for root growth. Plant Soil 192, 37-48.

Chandra A, Singh R and Rathore V S 1979 P-32 study on root distribution in eureka round lemon in the submontane Himalaya region. Indian J. Agric. Sci. 49, 958-961.

Comerford M B, Kidder G and Mollitor A V 1984 Importance of subsoil fertility to forest and non-forest plant nutrition. In Forest Soils and Treatment Impact. Ed. E L Stone. pp. 394-404. Proc. North Am. Forest Soils Conf., Knoxville TN. University of Tennessee.

Cox M S and Barber S A 1992 Soil-phosphorus levels needed for equal P-uptake from 4 soils with different water contents at the same water potential. Plant Soil 143, 93-98.

Dambrine E, Loubet M, Vega J A and Lissarague A 1997 Localization of mineral uptake by roots using Sr isotopes. Plant Soil 192, 129-132.

Dell B, Bartle J R and Tacey W H 1983 Root occupation and root channels of Jarrah forest subsoils. Aust. J. Bot. 31, 615-627.

Dhandar D G and Singh R 1989 Root studies in grapefruit (Citrus paradisi Macf.) using radiotracer technique. Sci. Hort. 40, 113118.

Dijkstra F A and Smits M M 2002 Tree species effects on calcium cycling: the role of calcium uptake in deep soils. Ecosystems 5, 385-398.

Faby R and Naumann W D 1986 Einfluß der N-Düngung von Apfelkulturen auf Nitratgehalte im Boden, stickstoffhaltige Reservestoffe im Baum und Ertrag. Z. Pflanzern. Bodenk. 149, 639-657.

Farina M P W, Channon P and Thibaud G R 2000 A comparison of strategies for ameliorating subsoil acidity: II. Long-term soil effects. Soil Sci. Soc. Am. J. 64, 652-658.

Fernendez J E, Moreno F, Cabrera F, Arrue J L and Martinandra J 1991 Drip irrigation, soil characteristics and the root distribution and root activity of olive trees. Plant Soil 133, 239-251.

Forde S T M 1972 Effect of dry season drought on uptake of radioactive phosphorus by surface roots of the oil palm (Elaeis guineensis Jacq.). Agron. J. 64, 622-623.

Fox R L and Lipps R C 1955 Subirrigation and plant nutrition I. Alfalfa root distribution and soil properties. Soil Sci. Soc. Am. Proc. 19, 468-473.

Gale M R and Grigal D F 1987 Vertical root distributions of northern tree species in relation to successional status. Can. J. For. Res. 17, 829-834.

George S J, Mohan Kumar B, Wahid P A and Kamalam N V 1996 Root competition for phosphorus between the tree and herbaceous combonents of silvopastoral systems in Kerala, India. Plant Soil 179, 189-196.

Haag D 1997 Root distribution patterns in a polycultural system with local tree crops on an acid upland soil in central Amazonia. MSc Thesis, University of Bayreuth, Germany, $88 \mathrm{pp}$.

Hansen P 1974 Drainage depth for apple trees. Tidsskrift Planeauvl $78,46-52$.
Hartemink A E, Buresh R J, Jama B and Janssen B H 1996 Soil nitrate and water dynamics on sesbania fallow, weed fallow and maize. Soil Sci. Soc. Am. J. 60, 568-574.

Hase Y, Machida Y and Maotani T 1988 Influence of subsoil moisture on growth of Japanese persimmon and its fruit yield. Bull. Fruit Tree Res. Station (Akitsu, Japan) 7, 31-49.

Huxley P A, Patel R Z, Kabaara A M and Mitchell H W 1974 Tracer studies with ${ }^{32} \mathrm{P}$ on the distribution of functional roots of Arabica coffee in Kenya. Ann. Appl. Biol. 77, 159-180.

IAEA 1975 Root Activity Patterns of some Tree Crops. Technical Report Series No 170, International Atomic Energy Agency, Vienna, Austria, 154 pp.

Iyengar B R V and Keshava Murthy S V 1987 Spatial distribution of root activity in kagzi lime (Citrus aurantifolia, Swingle). Indian J. Hort. 44, 41-44.

Iyengar B R V and Shivananda T N 1990 Root-activity pattern in sweet orange (Citrus sinensis) during different seasons. Indian J. Agric. Sci. 60, 605-608.

Iyengar B R V, Keshava Murthy S V and Shivananda T N 1989 Root activity studies in grape (Vitis vinifera $\mathrm{L}$.) using radioactive ${ }^{32} \mathrm{P}$. Indian J. Hort. 46, 148-153.

Jobbágy E G and Jackson R B 2001 The distribution of soil nutrients with depth: global patterns and the imprint of plants. Biogeochemistry 53, 51-77.

Jackson R B, Canadell J, Ehleringer J R, Mooney H A, Sala O E and Schulze E D 1996 A global analysis of root distributions for terrestrial biomes. Oecologia 108, 389-411.

Jamludheen V, Kumar B M, Wahid P A and Kamalam N V 1997 Root distribution pattern of wild jack tree (Artocarpus hirsutus Lamk.) as studied by ${ }^{32} \mathrm{P}$ soil injection method. Agrofor. Syst. 35, 329-336.

Jayasree Sankar S, Wahid P A and Kamalam N V 1988 Absorption of soil-applied radiophosphorus by black pepper vine and support tree in relation to their root activities. J. Plant. Crops 16, 73-87.

Jeschke W D and Pate J S 1995 Mineral nutrition and transport in xylem and phloem of Banksia prionotes (Proteaceae), a tree with dimorphic root morphology. J. Exp. Bot. 46, 895-905.

Kotur S C, Iyengar B R V and Shivananda T N 1997 Distribution of root activity in young 'Alphonso' mango (Mangifera indica) trees as influenced by season and growth. Indian J. Agric. Sci. 67, 113-116.

Kowalenko C G 1996 Interpretation of autumn soil tests for hazelnut. Can. J. Soil Sci. 76, 195-202.

Kurien S, Goswami A M and Deb D L 1992a Influence of season of flush on root activity in citrus using ${ }^{32} \mathrm{P}$. Trop. Agric. 69, 306314.

Kurien S, Goswami A M and Deb D L 1992b Root activity of two citrus rootstocks assessed using radiotracer techniques. J. Hort. Sci. 67, 87-94.

Lehmann J 2002 Nutrient flux control by trees for improving soil fertility in tropical agroforestry. In Management of Tropical Plantation-Forests and Their Soil-Litter System. Chapter 14. Ed. M V Reddy. pp. 351-377. Science Publishers Inc., Enfield, NH.

Lehmann J and Muraoka T 2001 Tracer methods to assess nutrient uptake distribution in multistrata agroforestry systems. Agrofor. Syst. 53, 133-140.

Lehmann J, Muraoka T and Zech W 2001 Root activity patterns in an Amazonian agroforest with fruit trees determined by ${ }^{32} \mathrm{P},{ }^{33} \mathrm{P}$ and ${ }^{15} \mathrm{~N}$ applications. Agrofor. Syst. 52, 185-197.

Manderscheid B, Schweisser T, Lischeid G, Alewell C and Matzner E 2000 Sulfate pools in the weathered substrata of a forested catchment. Soil Sci. Soc. Am. J. 64, 1078-1082. 
Marschner H 1986 Mineral Nutrition of Higher Plants. Academic Press, London, UK, 674 pp.

Matschonat G and Matzner E 1995 Quantification of ammonium sorption in acid forest soils by sorption isotherms. Plant Soil 168-169, 95-101.

Mekonnen K, Buresh R J and Jama B 1997 Root and inorganic nitrogen distribution in sesbania fallow, natural fallow and maize fields. Plant Soil 188, 319-327.

Messenger A S and Hruby B A 1990 Response of interveinally chlorotic red maple trees treated with medicaps or by soil acidification. J. Environ. Hort. 8, 5-9.

Odhiambo H O, Ong C K, Wilson J, Deans J D, Broadhead J and Black C 1999 Tree-crop interactions for below-ground resources in drylands: root structure and function. Ann. Arid Zone 38, 221237.

Pavan M A, Bingham F T and Peryea F I 1987 Influence of calcium and magnesium salts on acid soil chemistry and calcium nutrition of apple. Soil Sci. Soc. Am. J. 51, 1526-1530.

Peter I and Lehmann J 2000 Pruning effects on root distribution and nutrient dynamics in an acacia hedgerow planting in northern Kenya. Agrofor. Syst. 50, 59-75.

Plamboeck A H, Grip H and Nygren U 1999 A hydrological tracer study of water uptake depth in a Scots pine forest under two different water regimes. Oecologia 119, 452-460.

Poszwa A, Dambrine E, Ferry B, Pollier B and Loubet M 2002 Do deep tree roots provide nutrients to the tropical rainforest? Biogeochemistry 60, 97-118.

Purohit A G and Mukherjee S K 1974 Characterizing root activity of guava trees by radiotracer technique. Indian J. Agric Sci. 44, 575-581.

Ritchey K D, Feldhake C M, Clark R B and Sousa D M G 1995 Improved water and nutrient uptake from subsurface layers of gypsum-amended soils. In Agricultural Utilization of Urban and Industrial By-products. pp. 157-181. ASA Spec. Publ. 58. ASA, Madison, WI.

Saiz del Rio J F, Fernandez C E and Bellavita O 1961 Distribution of absorbing capacity of coffee roots determined by radioactive tracers. Am. Soc. Hort. Sci. 77, 240-244.

Sanchez P A 1995 Science in agroforestry. Agrofor. Syst. 30, 5-55.

Schroth G 1995 Tree root characteristics as criteria for species selection and systems design in agroforestry. Agrofor. Syst. 13, 125-143.

Schroth G 1999 A review of belowground interactions in agroforestry, focussing on mechanisms and management options. Agrofor. Syst. 43, 5-34.

Schroth G, Rodrigues M R L and D'Angelo S A 2000 Spatial patterns of nitrogen mineralization, fertilizer distribution and roots explain nitrate leaching from mature Amazonian oil palm plantation. Soil Use Manage. 16, 222-229.

Sheriff D W and Nambiar E K S 1995 Effect of subsoil compaction and three densities of simulated root channels in the subsoil on growth, carbon gain and water uptake of Pinus radiata. Aust. J. Plant Physiol. 22, 1001-1013.

Sobhana A, Aravindakshan M and Wahid P A 1989 Root activity pattern of banana under irrigated and rainfed conditions. J. Nucl. Agric. Biol. 18, 117-123.
Stone E L and Kalisz P J 1991 On the maximum extent of tree roots. For. Ecol. Manage. 46, 59-102.

Stone E L and Comerford N B 1994 Plant and animal activity below the solum. In Whole Reglith Pedology. Proceedings of a Symposium, Minneapolis. pp. 57-74. Soil Sci. Soc. Am. Spec. Publ. No. 34. Madison, WI.

Sumner M E 1995 Amelioration of subsoil acidity with minimum disturbance. In Subsoil Management Techniques. Eds. N J Jayawardane and B A Stewart. pp. 147-185. Lewis Publishers, Boca Raton, FL.

Toma M, Sumner M E, Weeks G and Saigusa M 1999 Long-term effects of gypsum on crop yield and subsoil chemical properties. Soil Sci. Soc. Am. J. 39, 891-895.

Ulrich A, Jacobson L and Overstreet R 1947 Use of radioactive phosphorus in a study of the availability of phosphorus to grape vines under field conditions. Soil Sci. 64, 17-28.

Van Noordwijk M and Brouwer G 1991 Review of quantitative root length data in agriculture. In Plant Roots and their Environments. Eds. B L McMichael and H Persson. pp. 515-525. Elsevier, Amsterdam.

Van Noordwijk M and Purnomosidhi P 1995 Root architecture in relation to tree-soil-crop interactions and shoot pruning in agroforestry. Agrofor. Syst. 30, 161-173.

Van Noordwijk M, Widianto, Heinen M and Hairah K 1991 Old tree root channels on acid soils in the humid tropics: Important for crop root penetration, water infiltration and nitrogen management. Plant Soil 134, 37-44.

Van Noordwijk M, Lawson G, Soumare A, Groot J J R and Hairiah K 1996 Root distribution of trees and crops: competition and/or complementarity. In Tree-Crop Interactions: A Physiological Approach. Eds. C K Ong and P Huxley. pp. 319-364. CAB International, Wallingford.

Vasu K, Varadan K M, Velayudhan K T and Thomas T 1994 Activity and distribution pattern of roots of Gliricidia sepium. J. Nucl. Agric. Biol. 23, 24-28.

Wahid P A 2001 Radioisotope studies of root activity and root-level interactions in tree-based production systems: a review. Appl. Rad. Isotopes 54, 715-736.

Wahid P A, Kamalam N V, Ashokan P K and Vidyadharan K K 1989a Root activity pattern of cashew (Anacardium ocidentale L.) in lateritic soil. J. Plant Crops 17, 85-89.

Wahid P A, Kamalam N V, Ashokan P K and Vikraman Nair R 1989b Root activity pattern of cocoa (Theobroma cacao). J. Nucl. Agric. Biol. 18, 153-156.

Wahid P A, Kamalam N V and Anilkumar K S 1993 Coconut. In Rooting Patterns of Tropical Crops. Eds. M A Salam and P A Wahid. pp 188-203. Tata McGraw-Hill, New Delhi.

White A W 1982 Effects of topsoil-subsoil fertilizer and lime amendments on top and root growth of 'Stuart' pecan seedling in a simulated Norfolk soil profile. HortScience 17, 380-381.

Yocum W W 1937 Root development of young delicious apple trees as affected by soils and cultural treatment. Univ. Nebraska Agric. Exp. Stat. Bull. 95: 1-55. 